\title{
Podkasany rym
}

\author{
Precz mi z Febem! - Febus żak, \\ Precz z harmonią, czczy to dym! \\ Wiwat modnych wieszczów smak, \\ Wiwat podkasany rym!
}

Tak pisał Stanisław Okraszewski, poeta późnego oświecenia, ośmieszając jednozgłoskowe, niemiłe dla ucha, współbrzmienia ${ }^{1}$. Rym męski, oparty na akcencie oksytonicznym, w polskiej poezji pojawił się późno i występował rzadko. Różnoakcentowe współbrzmienia obecne w wierszach średniowiecznych w toku ewolucji systemów wersyfikacyjnych zostały niemal całkowicie wyparte przez rymy żeńskie, stanowiące jedną z ważnych konstant sylabizmu w jego kanonicznej, ustanowionej przez Jana Kochanowskiego wersji. Konwencja ta została zmodyfikowana dopiero na przełomie XVIII i XIX wieku, gdy rym męski zaczął pojawiać się w polskiej liryce, zwykle w utworach o lekkiej, frywolnej bądź satyrycznej tematyce. Wyrazistość brzmieniowa oraz dobitny charakter oksytonicznej klauzuli (często dodatkowo eksponowany przez użycie wyrazów jednozgłoskowych) sprawiły, że rymy męskie postrzegane były jako ostentacyjne, nieco przesadne, karykaturalne, niestosowne do opiewania wysokich idei czy subtelnych emocji. Nie bez wpływu na takie postrzeganie wierszy o oksytonicznych klauzulach było skojarzenie z linią intonacyjną jambów - starożytnego gatunku metrycznej poezji satyrycznej wyrosłego z kultu bogini Demeter. Na przełomie XVIII i XIX wieku jambami nazywano utwory o charakterze satyry politycznej, które przybierały postać zjadliwych i ośmieszających inwektyw, nie podejmujących jednak antycznych miar wierszowych.

Jako jeden z pierwszych w historii literatury polskiej rymu męskiego używał Ignacy Krasicki, eksperymentując z systemem sylabicznym, twórczo i swobodnie traktując jego rygory. W bajce Lwica i maciora oksytoniczne współbrzmienie spina dwa ostatnie wersy, dobitnie podkreślając pointę wiersza, ale i różnicując idiolekty obu tytułowych bohaterek. Rozwlekła wypowiedź świni, chwalącej się licznym potomstwem, została ujęta w ramy regularnego, typowego dla polskiej bajki ośmiozgłoskowca z tendencją do paroksytonicznej stabilizacji akcentu przed średniówką i w klauzuli. Zwięzła riposta lwicy to dwa wersy siedmiozgłoskowe połączone wyrazistym rymem męskim, w którym obszar współbrzmienia obejmuje nie tylko końcową samogłoskę sylab otwartych, ale i poprzedzającą ją spółgłoskę: „Ródź ty dziesięć, cztery, dwa, / Ja jednego, ale lwa"2. Bajki nowe, wśród których znalazł się przywołany wyżej utwór, są późniejsze od wydanych w 1779 roku Bajek i przypowieści. Ukazały się dopiero po śmierci Krasickiego, w edycji dzieł zebranych przygotowywanej przez Franciszka Ksawerego Dmochowskiego w 1802 roku. Tym samym zdecydowana wypowiedź lwicy otwiera dziewiętnastowieczną historię rymów męskich, coraz wyraźniej obecnych w polskiej liryce, stosowanych w wierszach o rozmaitej tematyce, utrzymanych w różnorodnych konwencjach.

\footnotetext{
${ }^{1}$ S. Okraszewski, Panegiryk nowych a szczęśliwie wynalezionych rymów, „Pamiętnik Warszawski” 1816, t. VI, s. 68.

${ }^{2}$ I. Krasicki, Lwica i maciora, [w:] tegoż, Bajki, oprac. J. Sokolski, Wrocław 1989, s. 92.
} 
W 1816 roku na łamach „Pamiętnika Warszawskiego” opublikowane zostały dwa utwory Kazimierza Brodzińskiego, rymowane po części oksytonicznie ${ }^{3}$. W liryku Złe i dobre, zbudowanym z czterowersowych strof utrzymanych w rytmie tetrapodii trocheicznej z kataleksą w drugim i czwartym wersie, rymy męskie pojawiają się właśnie w owych katalektycznych klauzulach. Są dokładne, ale niezbyt kunsztowne (na 37 par rymowych tylko trzy wydają się głębokie, a cztery bogate). Pozostałe rymy żeńskie (37 par) również nie są oryginalne i tylko nieliczne można uznać za pogłębione (zaledwie w czterech przypadkach). Wiersz roztrząsa dwoistą naturę świata, w którym cierpienie przeplata się z radością, zło z dobrem, powodzenie i sukces z niedolami i nędzą.

Z piekłem niebo łańcuch wije

$\mathrm{Z}$ cierniem razem spaja kwiat,

Przez złe tylko dobrze żyje,

$\mathrm{Na}$ tej wadze stoi świat.

(Brodziński, Złe i dobre)

Przeplot rymów męskich i żeńskich nie jest jednak odzwierciedleniem ambiwalentnego obrazu świata, ale raczej strukturalnym naśladowaniem ludowych melodii, w których rytm oberka czy dumki (w końcowej frazie) wymuszał zaakcentowanie ostatniej miary taktu. Silne oddziaływanie tradycji ludowej można zaobserwować w wielu utworach Brodzińskiego. Jest ono też bardzo wyraźne w innym liryku o znaczącym tytule Dumka, opublikowanym w kolejnym numerze „Pamiętnika Warszawskiego”. Historia Czesława płaczącego na grobie Haliny czerpie z ludowych pieśni ukraińskich o charakterze elegijnym i balladowym, utrzymanych zazwyczaj w tęsknej tonacji, tematycznie związanych z ojczystym pejzażem i lokalną obyczajowością. Nieszczęsny kochanek konwencjonalnie wspomina utraconą dziewczynę:

Już cię nie opłaczę,

Już cię nie zobaczę

Drogi cieniu mój!

Na moje płakanie

Łez więcej nie stanie,

Słaby już ich zdrój.

Połowa ja ciebie

Po twoim pogrzebie

Błądzę noc i dzień,

Oddycham cierpieniem,

Za znikłym już cieniem

Chodzę żywy cień.

(Brodziński, Dumka)

${ }^{3}$ K. Brodziński, Złe i dobre, „Pamiętnik Warszawski” 1816, t. VI, s. 335-341; tegoż, Dumka, „Pamiętnik Warszawski” 1816, t. VI, s. 481-484. 
Tekstowi towarzyszy nutowy zapis linii melodycznej, która determinuje oksytoniczny akcent w trzecim i szóstym wersie każdej z jedenastu sekstyn. Większość współbrzmień ma banalny charakter (np. los-głos, pas-las, gór-chmur), a poecie nie udało się uniknąć powtórzeń wynikających z ograniczonego repertuaru wyrazów jednozgłoskowych w polszczyźnie (rym dzień-cień pojawia się w wierszu dwukrotnie). Pogoń za rymem w wielu wersach determinuje też wprowadzenie inwersji lub przerzutni, które zaburzają gatunkową konwencję utworu, ale pozwalają umieścić jednozgłoskowy wyraz w klauzuli.

Nic dziwnego, że w pierwszej połowie XIX wieku rym męski wciąż budził wielkie emocje. Kilka miesięcy przed opublikowaniem przywołanych wyżej utworów Brodzińskiego na łamach „Pamiętnika Warszawskiego” ukazał się persyflażowy utwór Stanisława Okraszewskiego Panegiryk nowych a szczęśliwie wynalezionych rymów ${ }^{4}$, oparty wyłącznie na niewyszukanych wspó1brzmieniach oksytonicznych utrzymanych w układzie krzyżowym. Rym męski, prześmiewczo nazwany „kusym” i „podkasanym” został przez Okraszewskiego porównany do krzyku indyka, hałasu maszyn $\mathrm{w}$ tartaku, zestawiony z terkotem werbli i odgłosami strzelaniny. Zastosowanie typowego dla epoki „kryterium ucha” pozwoliło autorowi wiersza zaklasyfikować tego rodzaju współbrzmienia jako niezgodne $\mathrm{z}$ harmonią, a poetów, którzy się nimi posługują, wskazać jako godnych uwieńczenia nie laurem, a wieńcem z pokrzyw.

Na prześmiewczy utwór Okraszewskiego zareagował Józef Franciszek Królikowski, który w kolejnym tomie tego samego czasopisma opublikował publicystyczny tekst Uwagi nad jednozgłoskowym rymem ${ }^{5}$, w rozsądny i wyważony sposób zastanawiając się nad sposobem funkcjonowania rymów męskich w polszczyźnie. „Czyli jest to skutkiem ubóstwa języka naszego, albo uporu poetów, czyli też wyższości smaku poezji naszej nad poezją wszystkich innych języków?" - pytał ${ }^{6}$. Porównanie z literaturą powstającą w innych językach europejskich, w których rym męski funkcjonował już od dawna i nie budził żadnych kontrowersji, pozwoliło Królikowskiemu docenić nowy model mowy wiązanej, wymagający od poety kunsztu i sprawności warsztatowej dużo wyższej niż w konwencjonalnych sposobach rymowania. Uznanie rymów męskich jako pełnoprawnych współbrzmień możliwych do stosowania w poezji wysokiej umożliwiłoby też, zdaniem Królikowskiego, rozwój polskiej opery, w której muzyka niekiedy wymusza wprowadzenie oksytonicznej klauzuli.

Zgodnie z polemicznym duchem epoki oświecenia, Okraszewski odpowiedział na artykuł oponenta w jednym z kolejnych numerów „Pamiętnika Warszawskiego”. Jego tekst pt. Myśli moje nad praca pana Franciszka Królikowskiego o zastosowaniu poezji do muzyki ${ }^{7}$ wywołał kolejne wystąpienia anonimowych autorów, sygnowane S. P. oraz Parafianin znad Buga. Kolejne głosy w zasadzie nie wnoszą już nowych argumentów w kwestii zasadności rymu męskiego, który z upływem czasu znajduje swoje miejsce w polskiej wersyfikacji. Publikacja Okraszewskiego warta jest jednak uwagi, zastosowano w niej bowiem rzadką w oświeceniowych polemikach strategię antyprzy-

\footnotetext{
${ }^{4}$ S. Okraszewski, Panegiryk nowych a szczęśliwie wynalezionych rymów, s. 68-69.

${ }^{5}$ J.F.K. [Józef Franciszek Królikowski], Uwagi nad jednozgłoskowym rymem, „Pamiętnik Warszawski” 1817, t. VIII, s. 286-297.

${ }^{6}$ Tamże, s. 287.

${ }^{7}$ S. Okraszewski, Myśli moje nad rozprawa pana F. Królikowskiego o zastosowaniu poezji do muzyki, „Pamiętnik Warszawski" 1918, t. X, s. 89-102.
} 
kładu. Autor wykazał niezgodność intonacyjno-akcentowego systemu polszczyzny z prozodią starożytną, omówił niemożność odtworzenia w polskim wierszu niektórych stóp metrycznych (przede wszystkim jambów), wspierając swój tok rozumowania jambiczną elegią, spreparowaną specjalnie na użytek tego wystąpienia. Okraszewski rozpoczyna swój wiersz nieco koślawą apostrofą do Muzy, która niosła natchnienie rzymskim twórcom elegii - Tybullowi i Owidiuszowi:

Zanuć nad Wisły kryształem o Muzo lubego Tybulla,

Lackich mi nie płoń się stron, owszem ukochaj ich dźwięk.

Mógł przecie Nazo pieszczony, twardą praszczurów mych mową,

W czarny wpatrując się Pont, sławić swą Julią i Rzym.

Prawaś Ty Muzo rzymianka, wywiąż się wywiąż po rzymsku.

Pomnij do jakich łask, święte ma prawo twój gość...

Przywołana wyżej elegia zatytułowana Wspomnienia okolic Rzymu istotnie jest utworem dość niskiego lotu i nieuchronnie pobudza do postawienia pytania, czy jej grafomański charakter to dowód na brak możliwości podporzadkowania polszczyzny jambicznemu metrum, czy może tylko świadectwo nieudolności poetyckiej Okraszewskiego. Historia literatury pokazała bez wątpienia, że jamb - choć nieprzyjazny rodzimemu systemowi intonacyjnemu - może doskonale funkcjonować w polskiej poezji. Utwory o toku jambicznym, pozbawione kataleksy, hiperkataleksy i innych odstępstw od regularności metrum pisywał już Adam Mickiewicz, a później choćby Julian Tuwim.

Programowo nieudana elegia Okraszewskiego wskazuje więc nie tyle na ograniczenia polszczyzny, co odzwierciedla stan świadomości teoretycznoliterackiej pod koniec drugiej dekady XIX wieku. Poczucie obcości rymu męskiego łączy się w niej z przekonaniem o wysokiej randze elegii - cenionego gatunku lirycznego wnikliwie omawianego we wszystkich sztukach rymotwórczych epoki. Paradoksalne odrzucenie oksytonicznej klauzuli z równoczesnym dowartościowaniem starożytnej konwencji elegii musiało zdeterminować przekształcenie ram gatunkowych i spowodować odejście od dystychu elegijnego. Poniekąd dzięki żywiołowej niechęci i nieufności wobec rymu męskiego, która czasowo uniemożliwiła wszelkie próby zrekonstruowania pentametru, wyznaczniki gatunku w literaturze polskiej po części przemieściły się z planu wyrażania do planu treści - pierwszoplanowym wyróżnikiem elegii stała się tematyka refleksyjna i charakterystyczny ton smutnego rozpamiętywania. A rym męski, choć znalazł swoje miejsce w polskiej poezji, dla twórców wierszy elegijnych już na zawsze pozostał nieobligatoryjny.

\section{Agnieszka Kwiatkowska}

${ }^{8}$ S. Okraszewski, Wspomnienia okolic Rzymu, „Pamiętnik Warszawski” 1818, t. X, s. 92. 


\title{
SEOWA KLUCZOWE:
}

spór o zasadność rymu męskiego

\section{rym męski}

\author{
oksytoniczna klauzula
}

\begin{abstract}
AbSTRAKT:
Próby naśladowania starożytnego wiersza metrycznego w literaturze polskiej wiązały się z koniecznością zastosowania akcentu oksytonicznego w klauzuli. Wokół tego zjawiska w XVIII wieku wybuchł spór. Polemiści dyskutowali o możliwościach przeniesienia do polskiego wiersza struktury podawczej elegii oraz o funkcjonowaniu rymu męskiego, powiązanego z tym właśnie gatunkiem. Rym męski, postrzegany jako frywolny i lekki, w odczuciu oświeconych nie pasował do liryki nastrojowej i melancholijnej.
\end{abstract}




\section{NOTA O AUTORZE:}

Agnieszka Kwiatkowska - profesorka w Zakładzie Literatury XX Wieku, Teorii Literatury i Sztuki Przekładu UAM, bada funkcjonowanie tradycji w literaturze współczesnej. Autorka monografii Oświecenie w epokach następnych (2009), „Tradycja, rzecz osobista”. Julian Przyboś wobec dziedzictwa poezji (2011), Historia literatury dawnej dla poczqtkujacych i zainteresowanych (2015). 